\title{
Hydraulics Performance of Coastal Flood Control in Madukoro Area, Semarang City, Indonesia
}

\author{
Dian Wahyu Jatmiko \\ Public Works, Water Resource Management, and Spatial Planning Office, Semarang, INDONESIA \\ mahasheva99@gmail.com
}

\begin{abstract}
Madukoro area located on the northern coast of Semarang City has been prone to flooding caused by rainfall and seawater hightide. Ineffective flood control management and land subsidence are considered as the cause of this problem. In order to understand land subsidence effect and flood control performance, location, water surface height of the inundation in West Flood Canal, western part of Madukoro area need to analyze. Flood analysis was conducted using HEC-HMS software and rational method. Flow hydraulics on five channels, i.e. the West Flood Canal, Ronggolawe River, Karangayu River, Arterial Channel and Madukoro were analyzed using HEC-RAS software. Increasing levee level and additional water pumps in Madukoro and Ronggolawe were chosen as flood control alternatives. Its performance was investigated through software simulation. The results showed total runoff volume in all drainage channels for 2-years return period discharge was about $80 \%$ of capacity with $0.7 \mathrm{~m}$ water depth. Runoff volume in West Flood Canal with 50-years return period discharge was about 40\%. Land subsidence 4 $\mathrm{cm} /$ year affected the water level increase on West Flood Canal. Operation of 2 - 4 pump units could not significantly decrease water level at flood peak, yet increase flood recession time $6-8$ hours.
\end{abstract}

Keywords: madukoro drainage, rain runoff, water level increase, coastal flood

\section{INTRODUCTION}

There are two types of flood that hit Semarang City, i.e. the flood caused by rain and flood caused by seawater high-tide (coastal flood). One of the areas that hit by flood and coastal flood is the Madukoro Area. It is located in the downstream area of Garang Watershed, the western part of the West Flood Canal with $6.78 \mathrm{~km}^{2}$ of area (Figure 1). The flood occurs every year in the rainy season. The coastal flood happens on certain days every month. The time length and height of the inundation are also uncertain. This phenomenon is allegedly due to ineffective flood control infrastructure operation, continuous land subsidence, and sea level rise caused by global warming. According to Soedarsono (2007), groundwater extraction is a dominant factor of land subsidence in lower Semarang region, other than natural land compaction and loading. Sea level rise is of $2.65 \mathrm{~mm} / \mathrm{year}$ in Madukoro area (Wirasatriya et. al., 2006). Arief, et al. (2012) suggested that Madukoro Area is a region with high risk of being affected to coastal flood.

Flood and seawater high-tide controlling infrastructure are already existed, such as drainage channel, West Flood Canal (Kanal Banjir Barat-KBB), as well as several watergate and water pumps, yet until now they still have not been able to overcome the problem of the inundation.

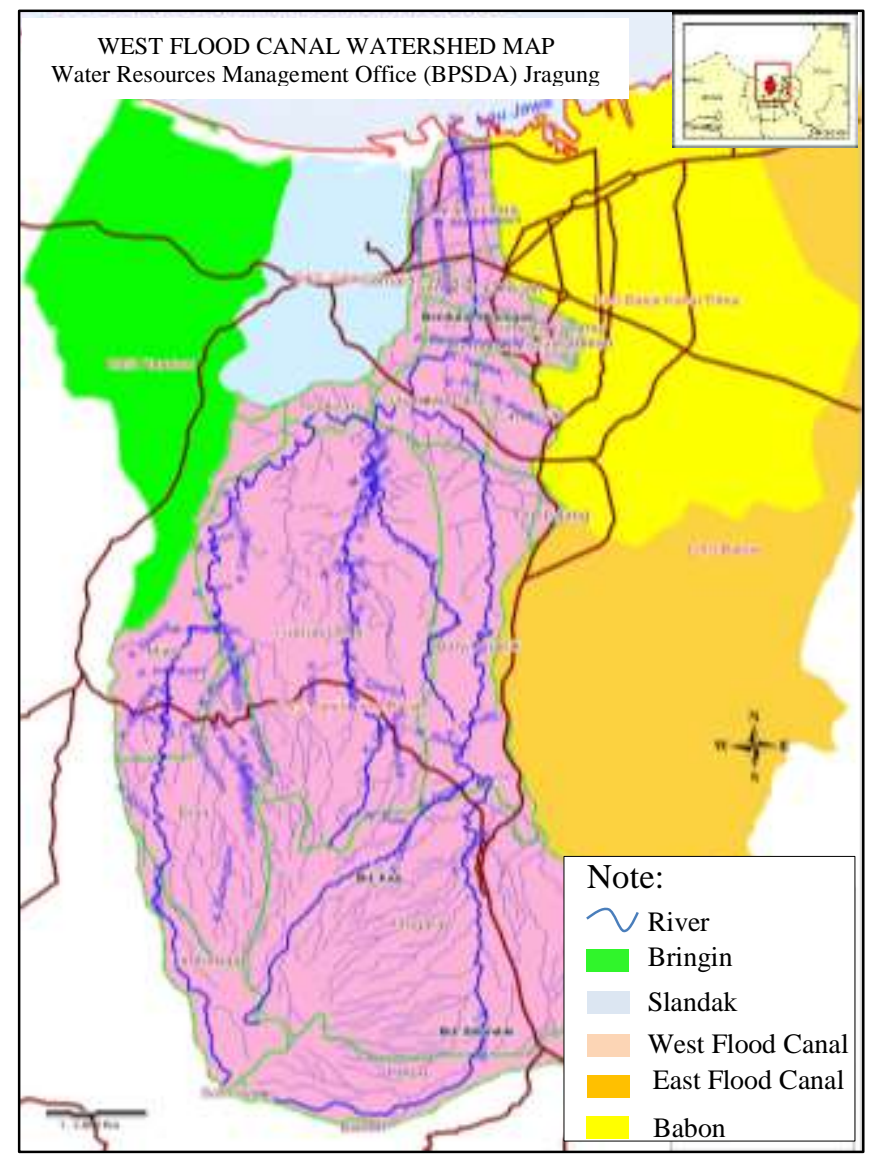

Figure 1. Map of Garang Watershed (PT. Tera Buana Manggala Jaya, 2007) 
The purpose of this research was to discover the cause of flood and coastal flood inundation in Madukoro area, the location where the coastal flood and flood water overflowed, the height of the runoff, to find out the ability of the existing infrastructure in controlling the flood and coastal flood, as well as to give recommendation on managing the flood and coastal flood in Madukoro area according to its priority scale.

This research only analyzed the flow simulation on the main channel (river) and collector drain but did not calculate the rate of land subsidence in Madukoro area. The land subsidence data from previously conducted researches were used. The land subsidence rate in a unit of $\mathrm{cm} /$ year was assumed to be linear for each year.

\section{RESEARCH METHOD}

This research was generally consisted of hydrology modeling and hydraulic modeling combination to analyze flood event in Madukoro Area (Figure 2). According to Cabral et al. (2015), flood early warning is very useful for the community in order to reduce flood impact. Early warning system is a combination of meteorology, hydrology, and hydraulic factors.

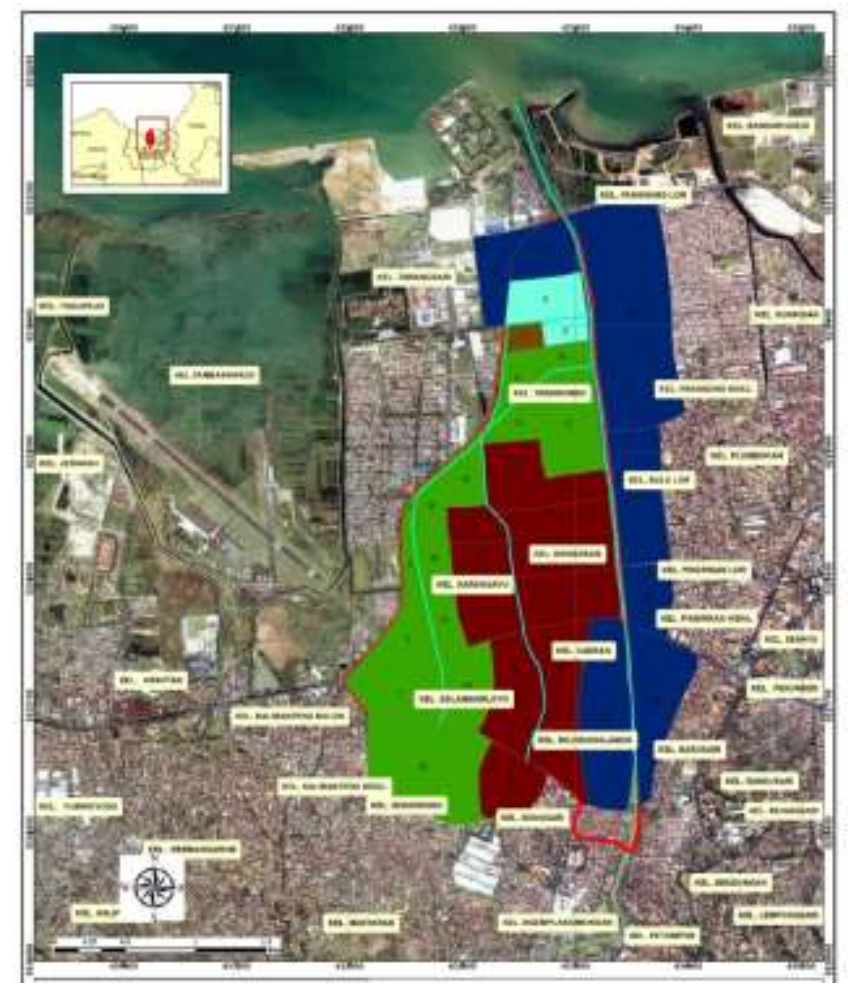

Note:

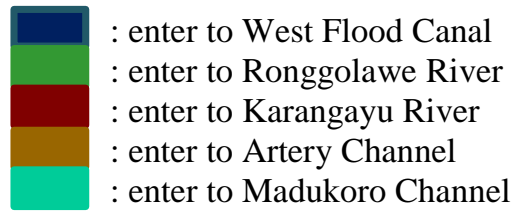

Figure 2. Size of drainage service area (PT. Tera Buana Manggala Jaya, 2007)

\subsection{Tidal Analysis}

The purpose of tidal data processing is to determine downstream boundary value of West Flood Canal channel for the flow simulation on HEC-RAS v.4.1.0 program. The boundary value that would be used was the stage hydrograph of Highest High Water Level (HHWL), in the form of stage hydrograph of the seawater tidal recording. Tidal data is the observation data and forecast data of hourly tidal for 30 days (per month) with 10 years data series $(2007$ - 2016) that was obtained from Maritime Meteorology Station of Tanjung Mas Semarang.

\subsection{Rainfall Analysis}

There are several methods to analyze watershed rainfall, such as arithmetic method, polygon Thiessen method, and isohyet method. Arithmetic Method (algebra average) method is the simplest method to calculate average rainfall in an area. According to Triatmodjo (2008), algebra average method would give the best result if the rain stations are evenly distributed in the watershed. Watershed rainfall is obtained by using the Equation 1. This method was used to rainfall data analysis in Madukoro Area. The rainfall analysis was conducted on research location by using data from two rain stations, the Simongan Station and Madukoro Station.

$P_{\text {average }}=\frac{P_{1}+P_{2}+P_{3}+\ldots+P_{n}}{n}$

In which $P_{\text {average }}$ is average areal rainfall, $P_{1}, P_{2}, P_{3}, \ldots, P_{n}$ are rainfall in station $1,2,3$, up to $n$, and $n$ is the total number of stations.

Polygon Thiessen calculates the weight of each station that represents its surrounding areas. Watershed rainfall is obtained with Equation 2 and Equation 3. This method was used to analyze the rainfall data in Garang Watershed. The rainfall analysis in Garang Watershed was conducted as an input for the HECHMS program. It used data from four rain stations, which were the Sumurjurang Station, Gunungpati Station, Mijen Station, and Simongan Station.

$$
H_{d}=\sum \alpha H_{i}
$$

$\alpha=\frac{L_{i}}{L}$

whereas $H_{d}$ is the average watershed rainfall $(\mathrm{mm}), H_{i}$ is the rainfall in each station $(\mathrm{mm}), \alpha$ is the Thiessen coefficient, $L_{i}$ is the area of each polygon $\left(\mathrm{km}^{2}\right)$, and $L$ is the watershed area size $\left(\mathrm{km}^{2}\right)$. 


\subsection{Frequency Analysis}

Frequency analysis is used to determine design rainfall and design flood certain return period based on the statistic properties of historical data, in order to obtain the future probability of rainfall and flood. Data distribution, in this case, is data that is arranged according to its value, for example, rainfall data that is sorted from the largest rainfall value down to the smallest rainfall value, and vice versa. Several methods of continuous probability distributions on hydrology field that are commonly used in frequency analysis are Normal, Log-Normal, Gumbel, Pearson, and Log Pearson Type III distribution. Some tests must be conducted in distribution analysis, in order to find whether the chosen distribution fit with the existing data. Statistical tests could be conducted with the ChiSquare method and Smirnov Kolmogorov method (Triatmodjo, 2008).

\subsection{Rainfall Distribution}

Intensity-Duration-Frequency (IDF) is presented in curve form that provides the relation between rainfall intensity as the ordinate, and rain duration as abscissa. If the short period rainfall data is not available, only the daily rainfall data that is available, the rainfall intensity could be calculated with Mononobe equation as shown in Equation 4 (Suripin, 2003).

$$
I_{T}^{t}=\left(\frac{R_{24}^{T}}{24}\right)\left(\frac{24}{t}\right)^{n}
$$

In which $I_{T}^{t}$ is the rainfall intensity on duration of $t$ with return period of $T$ year (mm/hour), $R_{24}^{T}$ is the maximum daily rainfall intensity on observed $\mathrm{T}$ $(\mathrm{mm} /$ day), $t$ is the rain duration (hour), $n$ is a constant (0.667).

\subsection{Rainfall-Runoff Transformation}

The method used for the calculation of peak flow on drainage channel was the USSCS Rational Method (1973) as shown in Equation 5.

$$
Q_{T}=0.278 C I_{(t c, T)} A
$$

Whereas $Q_{T}$ is the design discharge with return period of $T$ year $\left(\mathrm{m}^{3} / \mathrm{second}\right), C$ is the runoff coefficient $(0 \leq$ $C \leq 1), I_{(t c, T)}$ the rainfall intensity for concentration time of $t_{c}$ and return period of $T$ year ( $\mathrm{mm} /$ hour), and A is the area size of the watershed $\left(\mathrm{km}^{2}\right)$.

Runoff Coefficient is a very important variable in determining the design flood discharge. Several considered factors in determining the value of $\mathrm{C}$ are the soil infiltration rate, land slope, land cover crop, soil condition and characteristic as shown in Table 1 (Suripin, 2003).

Formula that was used to calculate the concentration time, $t_{c}$, is the Kirpich method as presented in Equation 6:

$t_{C}=0.06628 L^{0.77} S^{-0.385}$

In which $t_{c}$ is the concentration-time (hour), $L$ is the main river length from the upstream until the watershed's control point $(\mathrm{km}), S$ is the average slope of the river.

Table 1. Runoff Coefficient Value $(C)$

\begin{tabular}{lll}
\hline Runoff Area Type & $C$ Value \\
\hline Lawns & Sandy soil, flat 2\% & $0.50-0.10$ \\
& Sandy soil, average 2-7\% & $0.10-0.15$ \\
& Sandy soil, steep 7\% & $0.15-0.20$ \\
& Clay soil, flat 2\% & $0.13-0.17$ \\
& Clay soil, average 2-7\% & $0.18-0.22$ \\
& Clay soil, steep 7\% & $0.25-0.35$ \\
Business & Downtown Areas & $0.75-0.95$ \\
& Neighborhood Areas & $0.50-0.70$ \\
& Single family & $0.30-0.50$ \\
& Multi-unit, detached & $0.40-0.60$ \\
& Multi-unit, attached & $0.60-0.75$ \\
& Suburban & $0.25-0.40$ \\
Industrial & Apartment Areas & $0.50-0.70$ \\
& Light Areas & $0.50-0.80$ \\
& Heavy Areas & $0.60-0.90$ \\
& Parks, Cemeteries & $0.10-0.25$ \\
& Playgrounds & $0.20-0.35$ \\
Street & Railroad yard areas & $0.20-0.40$ \\
& Unimproved Areas & $0.10-0.30$ \\
Roofs & Asphaltic & $0.70-0.95$ \\
& Concrete & $0.80-0.95$ \\
& Stones & $0.70-0.85$ \\
& & $0.75-0.95$ \\
\hline
\end{tabular}

\subsection{Unit Hydrograph}

The used unit hydrograph was the Synthetic Unit Hydrograph Gama I as depicted in Figure 3. HSS Gama I consists of 4 main variables: the time of rising $(T R)$, peak discharge $(Q P)$, time base $(T B)$, and recession limb that is determined by the storage coefficient value $(K)$. 


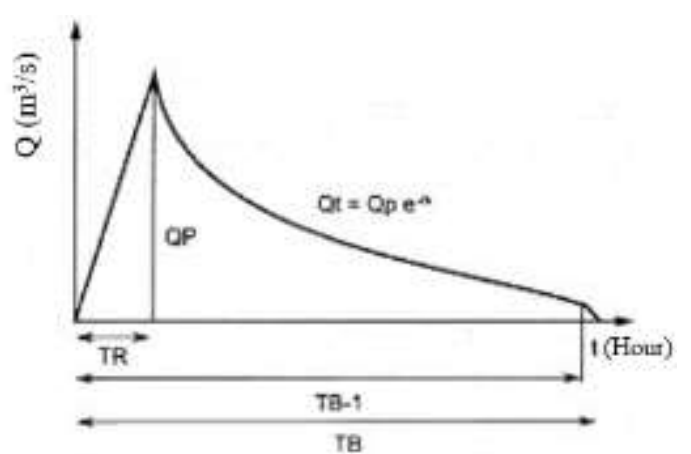

Figure 3. Synthetic Unit Hydrograph Gama I

HSS Gama I parameters are derived using Equation 7 to Equation 10 (Sri Harto, 2000):

$T R=0.43\left(\frac{L}{100 S F}\right)^{3}+1.0665$ SIM +1.2775

$Q P=0.1836 A^{0.5886} T R^{0.4008} J N^{0.2381}$

$T B=27.4132 T R^{0.1457} S^{-0.0986} S N^{0.7344} R U A^{0.2574}$

$K=0.5617 A^{0.1798} S^{-0.1446} S F^{-1.0897} D^{0.0452}$

In which $L$ is the length of main river $(\mathrm{km}), S F$ is the source factor, SIM is the symmetry factor, $A$ is the area size of the watershed $\left(\mathrm{km}^{2}\right), J N$ is the total of the river junction, $S$ is the average river slope, $S N$ is the source frequency, $R U A$ is the relative area of upstream watershed, and $D$ is the network density.

\subsection{Base Flow}

Sri Harto (2000) gave the empiric equation model for determining the base flow that is compiled on the theory of Gama I synthetic unit hydrograph. The base flow equation is shown in Equation 11.

$$
Q_{B}=0.475 A^{0.6444} D^{0.9430}
$$

$Q_{B}$ is the flow base discharge $\left(\mathrm{m}^{3} / \mathrm{s}\right), A$ is the area size of the watershed $\left(\mathrm{km}^{2}\right)$, and $D$ is the drainage density $\left(\mathrm{km} / \mathrm{km}^{2}\right)$.

\subsection{Sea Level Rise due to Global Warming}

Global climate change as the implication of global warming has caused instability in the lower layer atmosphere; the closest one, in particular, is the rising temperature, which caused melting glaciers that could affect the sea level rise. Sea level rise data due to global warming was obtained from NASA website titled global climate change which was accessed in 2017.

\subsection{Land Subsidence Analysis}

Land subsidence analysis used the data from a previous research conducted by Agency for the Assessment and Application of Technology (Badan Pengkajian dan Penerapan Teknologi-BPPT) (2006). It also used geological map of subsidence that was consisted in the appendix of the National Spatial Plan of Semarang City Year 2011-2030 from Development Planning Agency at Sub-National Level of Semarang City (2011).

\section{RESULT AND DISCUSSION}

\subsection{Scheme of Madukoro Area Drainage Channel}

On the HEC-RAS program, scheme of the river system is the initial data needed before another data is inputted. Drainage network scheme on Madukoro Area is shown in Figure 4. Drainage channel that was being simulated consisted of 5 channels, which are the West Flood Canal River, Ronggolawe River, Karangayu/Tawangmas River, Arteri Channel and Madukoro Channel. These channels are interconnected with each other.

\subsection{Data Processing of Tidal in Semarang Coast}

This research was aimed to discover the biggest influence of tidal to flood; therefore the data used was the highest tide which was occurred on October $23^{\text {rd }}$, 2008 (Table 2). Stage hydrograph of tidal on October $23^{\text {rd }}, 2008$ (adjusted with land elevation) is shown in Figure 5.

Table 2. Maximum tidal data on year 2007-2016

\begin{tabular}{lll}
\hline Year & Date & Maximum high tide $(\mathrm{cm})$ \\
\hline 2007 & 11 May & 125 \\
2008 & 23 October & 175 \\
2009 & 3 May & 150 \\
2010 & 4 October & 160 \\
2011 & 25 January & 120 \\
2012 & 12 May & 110 \\
2013 & 5 April & 110 \\
2014 & 4 Nov & 100 \\
2015 & 16 Dec & 110 \\
2016 & 14 May & 130 \\
\hline
\end{tabular}




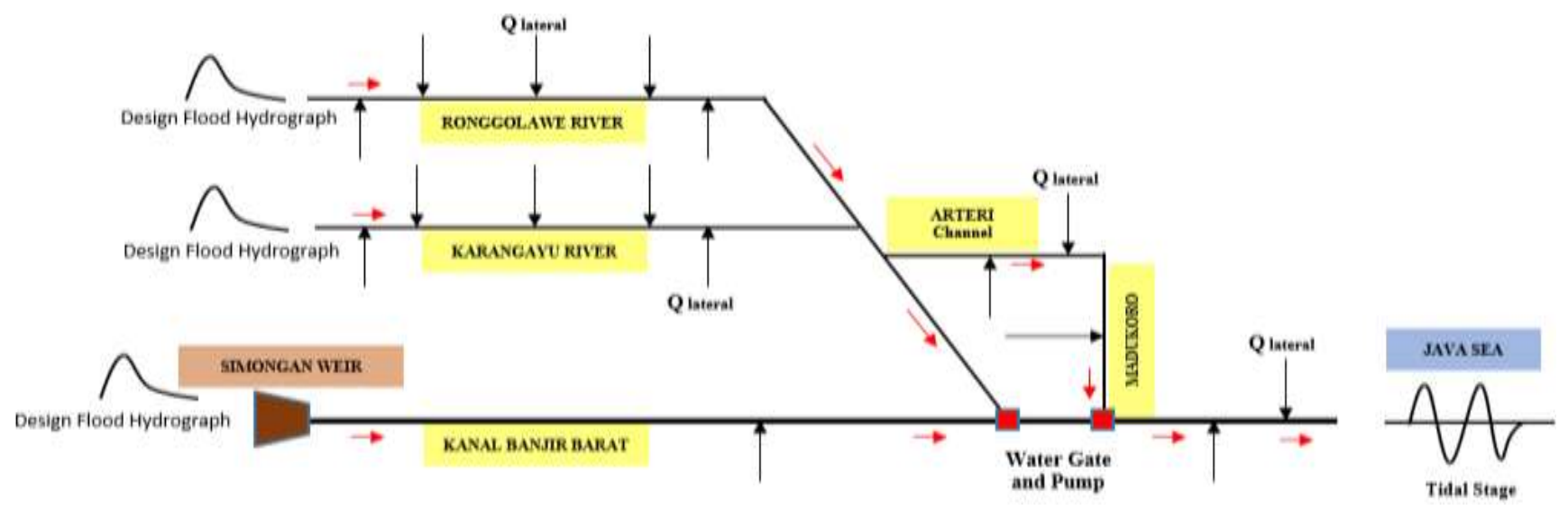

Figure 4. Scheme on drainage network of Madukoro Area

Recorded data would be firstly adjusted with the land elevation height. According to Maritime Meteorology Station of Semarang, the mean sea level (MSL) was on an elevation of $+60 \mathrm{~cm}$. This was meant that tidal record above $60 \mathrm{~cm}$ is high tide, and below $60 \mathrm{~cm}$ is low tide. Therefore, it was concluded that value of +60 tidal record $=+0$ land elevation.

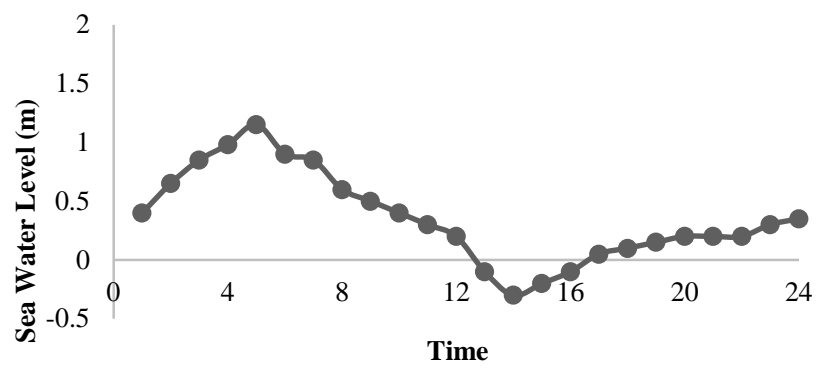

Figure 5. Stage hydrograph of tidal on October $23^{\text {rd }}, 2008$ (adjusted with land elevation)

\subsection{Hydrology Data Processing}

Design rainfall of Garang Watershed for several return periods obtained from analysis frequency are shown in Table 3.

Table 3. Design rainfall of Garang Watershed with Log Pearson III method

\begin{tabular}{ll}
\hline Return period (years) & Design rainfall $(\mathrm{mm})$ \\
\hline 2 & 68.05 \\
5 & 88.47 \\
10 & 103.54 \\
20 & 119.19 \\
25 & 124.42 \\
50 & 141.39 \\
100 & 159.62 \\
\hline
\end{tabular}

Rain distribution in Garang watershed that was calculated with ABM method was conducted with 5hours rain distribution pattern (Yuswardhanu, 2009). Rainfall data of Madukoro rain station area in 2008 was missing. In this case, the missing data were estimated using Normal Ratio Method as shown in Equation 12 below.

$P_{x}=\frac{1}{n} \sum_{i=1}^{n} P_{i} \frac{A_{n x}}{A_{n i}}$

In which $P_{x}$ is Madukoro Station's rainfall data on year 2008, $P_{i}$ is Simongan Station's rainfall data on year $2008(162 \mathrm{~mm}), A_{n x}$ is the average rainfall on Madukoro Station $(106.90 \mathrm{~mm}), A_{n i}$ is the average rainfall on Simongan Station $(125.40 \mathrm{~mm})$. The calculation resulted in $P_{\mathrm{x}}=138.10 \mathrm{~mm}$.

Design rainfall of Madukoro Area for several return periods obtained from analysis frequency is shown in Table 4.

Table 4. Design rainfall Madukoro Area with Log Pearson III method

\begin{tabular}{ll}
\hline Return period (years) & Design rainfall $(\mathrm{mm})$ \\
\hline 2 & 70.25 \\
5 & 86.19 \\
10 & 94.18 \\
20 & 100.45 \\
25 & 102.20 \\
50 & 107.05 \\
100 & 111.14 \\
\hline
\end{tabular}

From the chosen design rainfall (Log Pearson III method), calculation of intensity-duration-frequency then further conducted with Mononobe method, with result was shown in Figure 6. Design discharge of the drainage service area in Madukoro Area was calculated with Rational Method. This discharge data would be used as the lateral inflow in the drainage channel. Table 5 shows the calculation result of design flood discharge of Madukoro Area using Rational Method. 
Table 5. Design flood discharge on Madukoro Area with Rational Method

\begin{tabular}{|c|c|c|c|c|c|c|c|c|}
\hline \multirow{2}{*}{$\begin{array}{l}\text { Channel } \\
\text { Name }\end{array}$} & \multirow{2}{*}{$\begin{array}{l}\text { Area } \\
\text { Code }\end{array}$} & \multicolumn{7}{|c|}{ Design flood discharge $\left(\mathrm{m}^{3} / \mathrm{s}\right)$} \\
\hline & & Q2 & Q5 & Q10 & Q20 & Q25 & Q50 & Q100 \\
\hline \multirow[t]{7}{*}{ West Flood Canal } & 11 & 1.39 & 1.72 & 1.88 & 2.00 & 2.04 & 2.13 & 2.21 \\
\hline & 28 & 5.15 & 6.32 & 6.91 & 7.36 & 7.49 & 7.85 & 8.15 \\
\hline & 29 & 5.28 & 6.48 & 7.08 & 7.55 & 7.69 & 8.05 & 8.36 \\
\hline & 30 & 1.36 & 1.67 & 1.83 & 1.95 & 1.98 & 2.08 & 2.16 \\
\hline & 33 & 1.83 & 2.25 & 2.46 & 2.62 & 2.67 & 2.79 & 2.90 \\
\hline & 34 & 2.30 & 2.82 & 3.08 & 3.28 & 3.34 & 3.50 & 3.63 \\
\hline & 35 & 3.55 & 4.35 & 4.76 & 5.07 & 5.16 & 5.41 & 5.61 \\
\hline \multirow[t]{14}{*}{ Ronggolawe } & 1 & 0.71 & 0.87 & 0.95 & 1.01 & 1.03 & 1.08 & 1.12 \\
\hline & 2 & 0.55 & 0.68 & 0.74 & 0.79 & 0.80 & 0.84 & 0.87 \\
\hline & 3 & 0.58 & 0.72 & 0.78 & 0.83 & 0.85 & 0.89 & 0.92 \\
\hline & 4 & 0.51 & 0.63 & 0.69 & 0.73 & 0.75 & 0.78 & 0.81 \\
\hline & 9 & 0.99 & 1.21 & 1.33 & 1.42 & 1.44 & 1.51 & 1.57 \\
\hline & 10 & 0.91 & 1.12 & 1.22 & 1.30 & 1.33 & 1.39 & 1.44 \\
\hline & 12 & 2.26 & 2.78 & 3.04 & 3.24 & 3.29 & 3.45 & 3.58 \\
\hline & 13 & 0.55 & 0.67 & 0.74 & 0.79 & 0.80 & 0.84 & 0.87 \\
\hline & 16 & 0.92 & 1.13 & 1.24 & 1.32 & 1.34 & 1.41 & 1.46 \\
\hline & 19 & 0.82 & 1.01 & 1.10 & 1.18 & 1.20 & 1.25 & 1.30 \\
\hline & 20 & 0.84 & 1.03 & 1.13 & 1.21 & 1.23 & 1.28 & 1.33 \\
\hline & 23 & 0.68 & 0.83 & 0.91 & 0.97 & 0.98 & 1.03 & 1.07 \\
\hline & 24 & 1.63 & 1.99 & 2.18 & 2.33 & 2.37 & 2.48 & 2.57 \\
\hline & 32 & 2.01 & 2.47 & 2.69 & 2.88 & 2.93 & 3.06 & 3.18 \\
\hline \multirow[t]{10}{*}{ Karangayu } & 14 & 0.97 & 1.19 & 1.30 & 1.38 & 1.41 & 1.47 & 1.53 \\
\hline & 15 & 0.56 & 0.69 & 0.76 & 0.81 & 0.82 & 0.86 & 0.89 \\
\hline & 17 & 0.64 & 0.78 & 0.85 & 0.91 & 0.92 & 0.97 & 1.01 \\
\hline & 18 & 0.66 & 0.80 & 0.88 & 0.94 & 0.95 & 1.00 & 1.04 \\
\hline & 21 & 0.91 & 1.11 & 1.22 & 1.30 & 1.32 & 1.38 & 1.44 \\
\hline & 22 & 0.75 & 0.92 & 1.00 & 1.07 & 1.09 & 1.14 & 1.18 \\
\hline & 25 & 1.16 & 1.43 & 1.56 & 1.66 & 1.69 & 1.77 & 1.84 \\
\hline & 26 & 0.87 & 1.06 & 1.16 & 1.24 & 1.26 & 1.32 & 1.37 \\
\hline & 27 & 0.55 & 0.67 & 0.73 & 0.78 & 0.80 & 0.83 & 0.87 \\
\hline & 31 & 1.64 & 2.01 & 2.19 & 2.34 & 2.38 & 2.49 & 2.59 \\
\hline \multirow[t]{2}{*}{ Artery } & 5 & 0.40 & 0.50 & 0.53 & 0.57 & 0.58 & 0.61 & 0.63 \\
\hline & 7 & 0.76 & 0.93 & 1.02 & 1.08 & 1.10 & 1.15 & 1.20 \\
\hline \multirow[t]{2}{*}{ Madukoro } & 6 & 1.72 & 2.11 & 2.31 & 2.46 & 2.50 & 2.62 & 2.72 \\
\hline & 8 & 0.05 & 0.06 & 0.07 & 0.07 & 0.07 & 0.07 & 0.08 \\
\hline
\end{tabular}

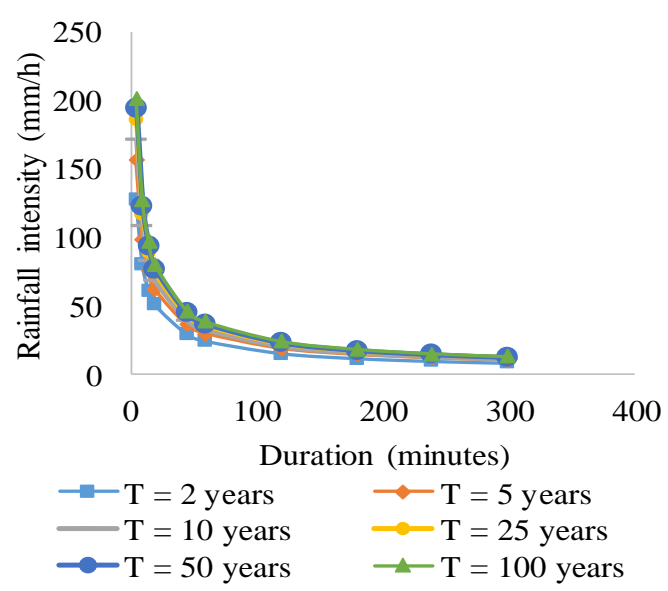

Figure 6. Intensity-Duration-Frequency Curve with Mononobe method
In carrying out the unsteady flow simulation with the HEC-RAS program, calculation of flood hydrograph is needed as the initial boundary condition on the river/channel upstream. Calculation of design flood discharge hydrograph was conducted with HEC-HMS program by modeling the parameter condition on Garang Watershed and control point was located in the Simongan Weir. Garang Watershed is divided into 6 sub-watersheds, which are the Kreo Hulu, Kripik Hulu, Garang, Kreo Hilir, Kripik Hilir, and Simongan. This modeling also included Jatibarang Dam parameter in the downstream of the Kreo Hulu Sub-watershed that has been operating since 2013 .

JICA (2000) has conducted a planning study on Jatibarang Dam that was included in the Final Report The Detailed Design of Flood Control, Urban Drainage and Water Resources Development in Semarang in 
Republic Indonesia (Component B: Jatibarang Multipurpose Dam Construction) Japan International Cooperation Agency (JICA) (2000). This study presented the amount of design discharge on the control point of Simongan Weir due to Jatibarang Dam operational. The result from comparison of HEC-HMS modeling and JICA study is shown in Table 6 .

Table 6. HEC-HMS simulation result versus JICA study

\begin{tabular}{lllll}
\hline \multirow{2}{*}{$\begin{array}{l}\text { Return } \\
\text { period } \\
\text { (years) }\end{array}$} & \multicolumn{4}{l}{ Peak discharge in Simongan Weir } \\
\cline { 2 - 5 }$\left(\mathrm{m}^{3} / \mathrm{s}\right)$ & HEC-HMS & $\begin{array}{l}\text { JICA } \\
\left(\mathrm{m}^{3} / \mathrm{s}\right)\end{array}$ & \multicolumn{2}{l}{ Difference } \\
\hline 5 & 388.20 & 400 & -11.80 & -2.95 \\
10 & 473.50 & 500 & -26.50 & -5.30 \\
25 & 602.60 & 620 & -17.40 & -2.81 \\
50 & 707.90 & 700 & 7.90 & 1.13 \\
100 & 827.20 & 790 & 37.20 & 4.71 \\
\hline
\end{tabular}

Hydraulic modeling with HEC-RAS program on the Ronggolawe River and Karangayu River was started from the upstream boundary, which is the railway road, to the downstream area. Flow hydrograph of the Ronggolawe River was the sum from the area 1, 3, 23, 24 , and 32. Flow hydrograph of the Karangayu River was the sum from the area 21, 22, 25, 26, 27, and 31 . The rational method calculation result shows that design flood discharge on the boundary point of railway road is shown in Table 7 .
Table 7. Flow hydrograph Ronggolawe and Karangayu upstream area.

\begin{tabular}{l|l|l}
\hline \multirow{2}{*}{$\begin{array}{l}\text { Return } \\
\text { period } \\
\text { (years) }\end{array}$} & \begin{tabular}{l} 
Design flood discharge \\
\cline { 2 - 3 }$\left(\mathrm{m}^{3} / \mathrm{s}\right)$
\end{tabular} & $\begin{array}{l}\text { Karangayu River } \\
\left(\mathrm{m}^{3} / \mathrm{s}\right)\end{array}$ \\
\hline$Q_{2}$ & 5.57 & 5.86 \\
$Q_{5}$ & 6.84 & 7.19 \\
$Q_{10}$ & 7.47 & 7.86 \\
$Q_{20}$ & 7.97 & 8.38 \\
$Q_{25}$ & 8.11 & 8.53 \\
$Q_{50}$ & 8.49 & 8.93 \\
$Q_{100}$ & 8.82 & 9.28 \\
\hline
\end{tabular}

\subsection{Flow Simulation Result with HEC-RAS v.4.1.0} Software

\subsubsection{Modeling drainage channel geometry}

Drainage channel geometry was modeled as close as possible with the actual condition as shown in Figure 7. This model was conducted with digitation of the Semarang City Satellite Imagery map. The data used were Semarang City Satellite Imagery map, Semarang City DEM obtained from the earthexplorer.usgs.gov, and data attained from measurement (situation, long section, cross section). The geometry construction was conducted by several approaches, such as:

a) West Flood Canal with three river reach (upstream, middle, and downstream) started from Bridge in the Simongan Weir Downstream (WF. 94/RS. 4469.39) until the estuary (WF.6/RS. 0) with length of \pm $4.369 \mathrm{~m}$.

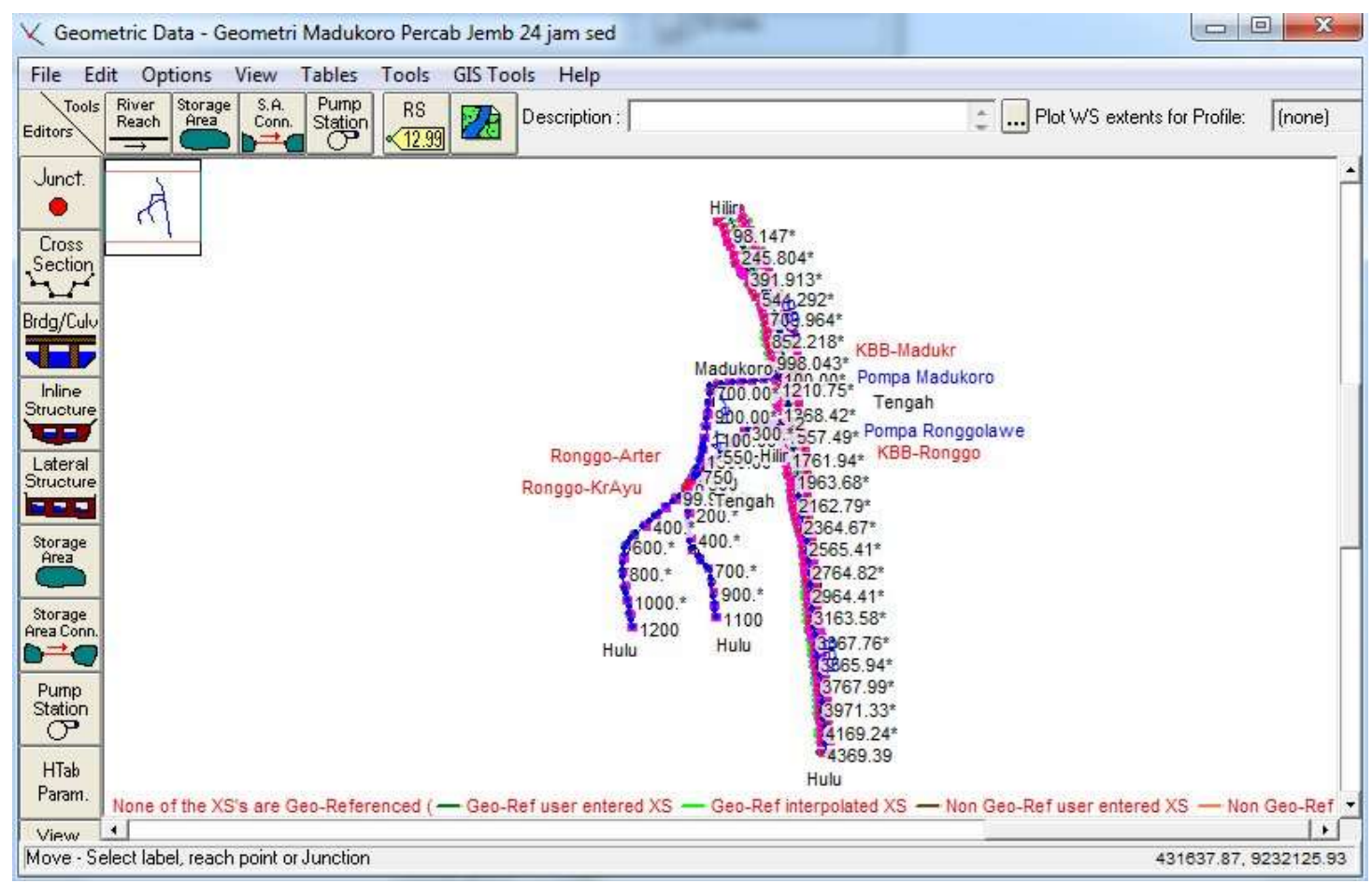

Figure 7. Madukoro Drainage Model in HEC-RAS Software 
b) Ronggolawe River three river reach (upstream, middle, and downstream) started from Railway (R. 30/ RS.1200) until the junction with West Flood Canal (R. 52/RS. 0) with length of $\pm 1.200 \mathrm{~m}$.

c) Karangayu River with one reach started from Railway (KA. 4/RS. 1100) the junction with Ronggolawe River (KA. 15) with length of \pm 1.100 $\mathrm{m}$.

d) Artery Channel with one reach started from the junction with Ronggolawe River (A.2/RS. 1500) until the junction with the Madukoro Channel (A.0/RS. 700) with length of $\pm 800 \mathrm{~m}$.

e) Madukoro Channel with one reach started from the junction with the Artery Channel (P.6A/RS. 600) until the junction with West Flood Canal (P.0/RS.0) with length of $\pm 650 \mathrm{~m}$.

\subsubsection{River inline structure}

\section{a) Water gate}

There are two water gates that operate in the Madukoro drainage system, namely Madukoro Water Gate (RS.2) which has 3 gates, $100 \mathrm{~cm}$ width, $200 \mathrm{~cm}$ length, and Ronggolawe Water Gate (RS. 2) which has 8 gates, 210 $\mathrm{cm}$ width, and $350 \mathrm{~cm}$ length.

b) Culvert

Culverts can be found in Ronggolawe 1 Culvert (RS.725), Ronggolawe 2 Culvert (RS.550), Artery Culvert (RS.1425), and Madukoro Culvert (RS.670).

\subsubsection{Bridge/Culvert}

There are 8 (eight) bridge constructions on the Madukoro area drainage system, i.e. West Flood Canal Siliwangi Bridge (RS.3275), West Flood Canal Railway Bridge (RS. 2870), West Flood Canal North Artery Bridge (RS. 350), Ronggolawe/Anjasmoro Bridge (RS.350), Ronggolawe/Semarang Indah Bridge (RS.65), Karangayu Bridge (RS. 750), Madukoro Bridge (RS. 350), and Madukoro Bridge (RS.135).

\subsubsection{Pump station}

There are two operating pump stations in the Madukoro drainage system, which are the Madukoro pump station and Ronggolawe pump station. The pump type is the Axial Submersible brand of Grundfos KPA 500 KPL/55 KW pump with each capable of 600 liters/seconds.

\subsubsection{Result of flow simulation with HEC-RAS (unsteady flow simulation)}

HEC-RAS simulation would be conducted for 24 hours (1 day) because the inundation in Madukoro area never occurs more than 24 hours. Other than that, it was also to discover the influence of the pump station performance. The results of flow simulation with HECRAS program (unsteady flow) with 2-years return period design flood discharge $\left(Q_{2}\right)$ are as shown in Figure 8 to Figure 11 .

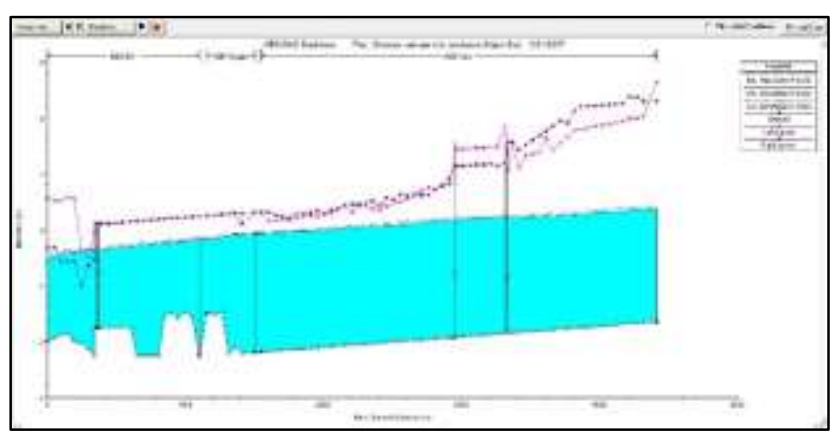

Figure 8. HEC-RAS simulation result on West Flood Canal (upstream-middle-downstream)

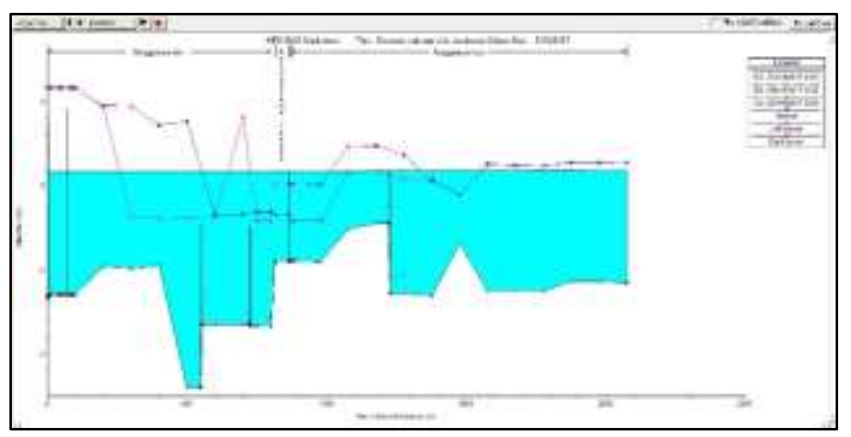

Figure 9. HEC-RAS simulation result on Ronggolawe River (upstream-middle-downstream)

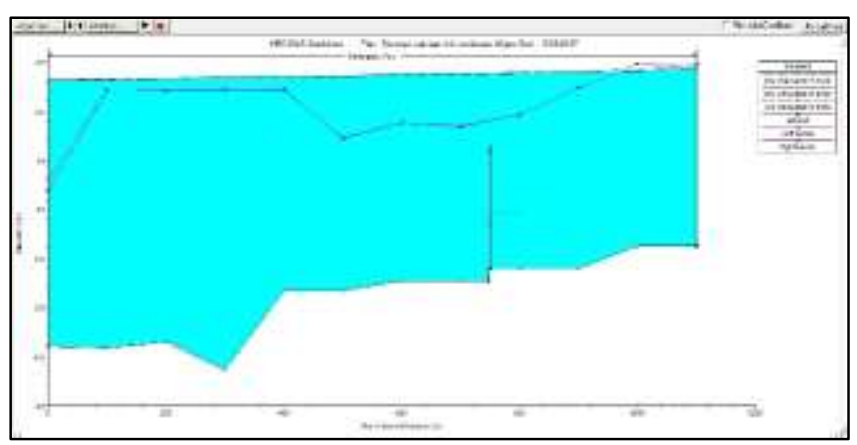

Figure 10. HEC-RAS simulation result on Karangayu River

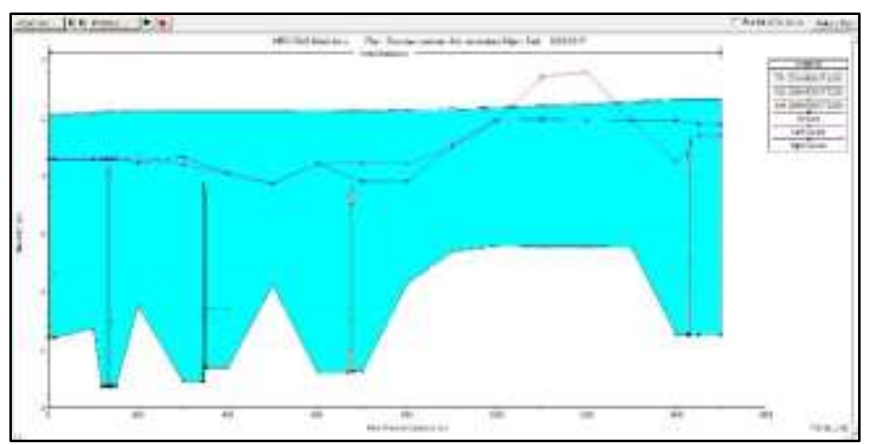

Figure 11. HEC-RAS simulation result on Madukoro Artery Channel

On Ronggolawe River, Karangayu River, and Madukoro Artery Channel, runoff occurred in almost every cross section. While West Flood Canal River was still relatively safe, runoff only occurred on 6 (six) cross sections on the downstream area near the coast for a 2- 
years return period design flood discharge. West Flood Canal was started to have runoff in the middle and downstream section with 50-years return period flood discharge $\left(Q_{50}\right)$ (Figure 12).

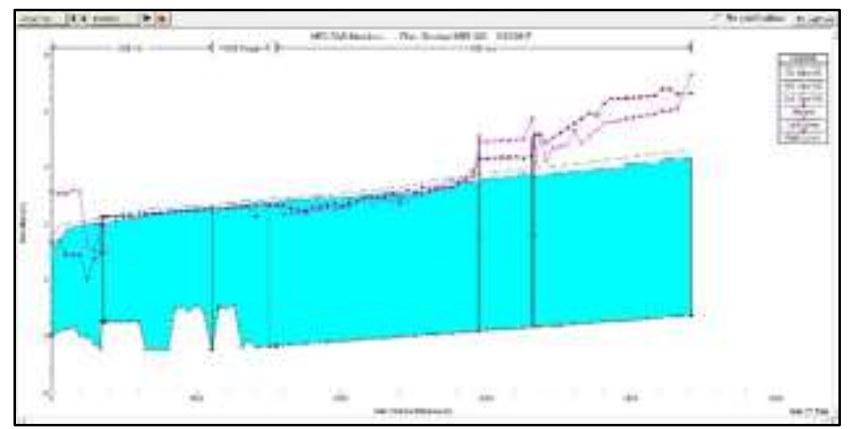

Figure 12. HEC-RAS simulation result on West Flood Canal $\left(Q_{50}\right)$

Flow simulation result on Madukoro Area showed that runoff occurred with 2-years return period design flood discharge. This matched with the condition on the field where flood/runoff occurs every year on the drainage channel of Madukoro Area. Further next, all simulation used 2-years return period flood discharge $\left(Q_{2}\right)$ for short term management.

\subsection{Sea Level Rise Due to Global Warming}

According to the research that was conducted by NASA (2017) on sea level rise due to global warming; the information obtained was that the sea level rise is of 3.4 $\mathrm{mm}$ /years (Figure 13). Therefore, sea level rise due to global warming could be ignored.

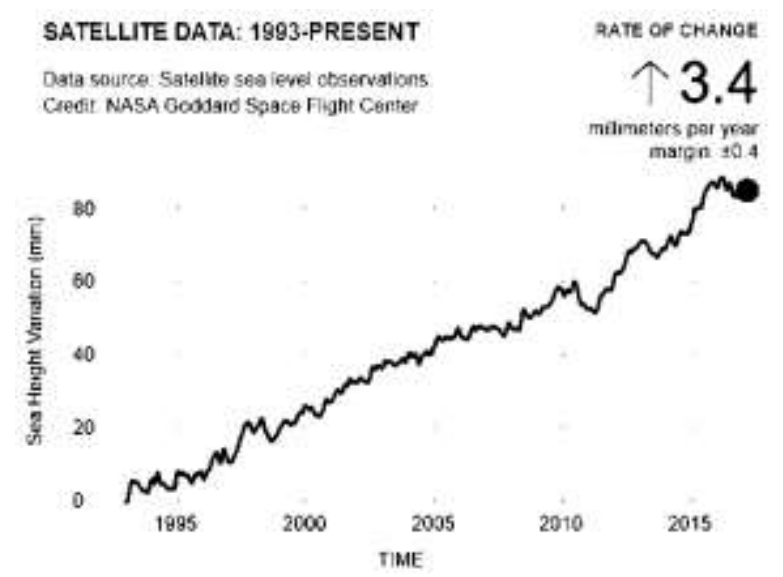

Figure 13. Sea level rise due to global warming (NASA, 2017)

\subsection{Land Subsidence}

As for the flood level rise simulation in the West Flood Canal due to land subsidence effect with the HEC-RAS program, the land subsidence was being analogized with sea level rise. According from the research of Agency for the Assessment and Application of Technology
(2006), the land subsidence in Madukoro area at West Flood Canal Bridge is as of $3.00 \mathrm{~cm} /$ years, and in Semarang Indah Housing is as of $5.00 \mathrm{~cm} /$ years. According to land subsidence geological map of Semarang City that was consisted in the appendix of the National Spatial Plan of Semarang City Year 20112030, land subsidence in Madukoro Area is as of 2-6 $\mathrm{cm} /$ years.

As for the land subsidence based on the trend line of sea level rise, the record on the tidal stakes that were conducted by Meteorological Climatological and Geophysical Agency of Maritime Station in Tanjung Mas Semarang showed result as displayed in Figure 14.

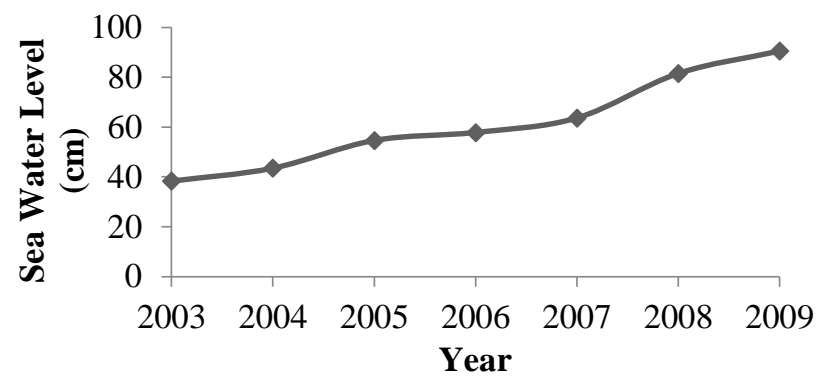

Figure 14. Graph on average sea level rise on Semarang City of year 2003-2009

Figure 14 showed that the average sea level rise based on the tidal record is larger, which is $7.45 \mathrm{~cm} /$ years, because the tidal recording stake was located in the Tanjung Mas Semarang Port that is $\pm 2 \mathrm{~km}$ from Madukoro Area; in which the land subsidence in Tanjung Mas Port is larger than in Madukoro area. Considering that the research location was in Madukoro Area, the data that sea level rise of $4 \mathrm{~cm} /$ years then was chosen. Land subsidence of $4.00 \mathrm{~cm} /$ years was analogized with sea level rise of $4.00 \mathrm{~cm} /$ years. This meant that sea level rise for 10 years (2016-2026) is of $40 \mathrm{~cm}=0.4 \mathrm{~m}$. Downstream boundary conditions of West Flood Canal (RS.0) was the stage hydrograph presented in Figure 15.

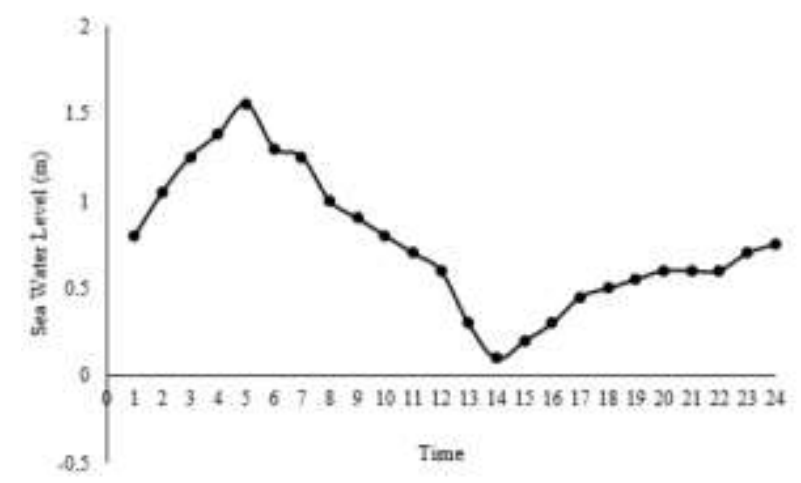

Figure 15. Stage hydrograph tidal prediction for year 2026 (adjusted with land elevation) for West Canal Flood boundary condition 


\subsection{Prediction result of flow simulation with HEC-} RAS for year 2026

Comparison of the result of West Flood Canal simulation with 10-years return period flood $\left(Q_{10}\right)$ between the conditions without land subsidence and with land subsidence. There was no requirement of 10years return period, yet just being simulated with 10years return period. The simulation results in HEC-RAS v.4.1.0 are depicted in Figure 16 and Figure 17.

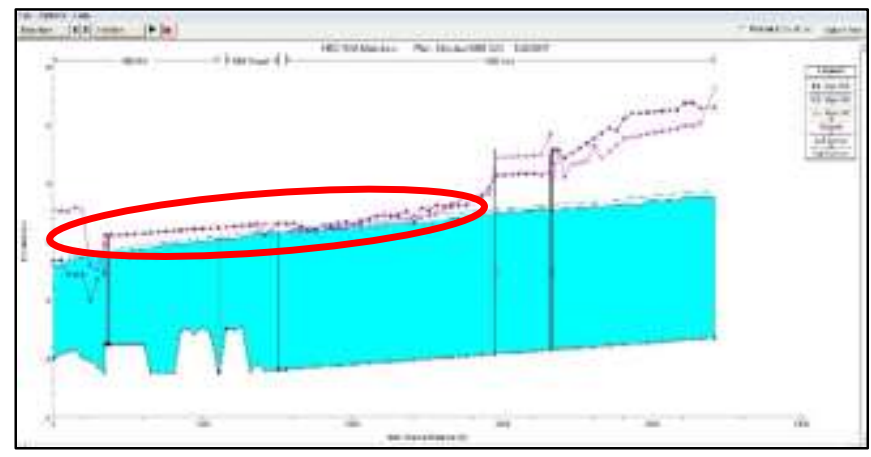

Figure 16. West Flood Canal HEC-RAS simulation result $\left(Q_{10}\right)$ without land subsidence

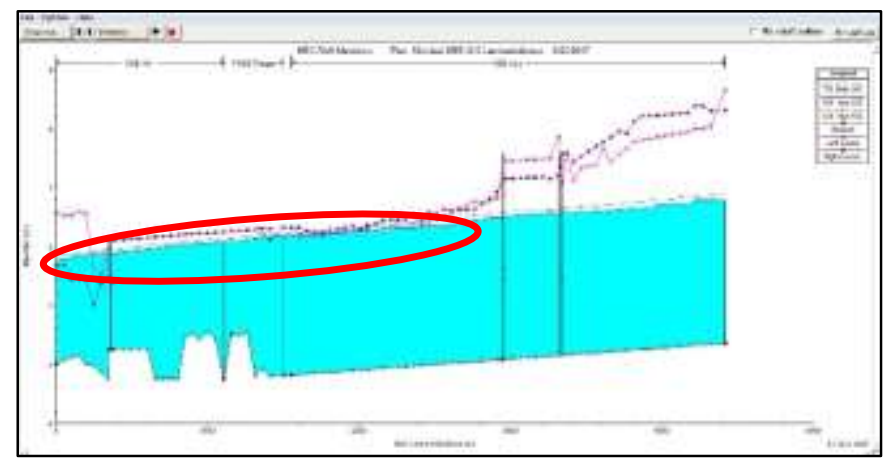

Figure 17. West Flood Canal HEC-RAS simulation result $\left(Q_{10}\right)$ with land subsidence

Height of the flood level in Madukoro Area is not affected by tidal rise (coastal flood) if the water gate is closed. Madukoro would suffer from coastal flood if the water gate is opened.

\subsection{Flood Controlling Infrastructure}

The influence of flood controlling infrastructure (inline structure) in form of water gate on the drainage channel in Madukoro Area was simulated with HEC-RAS with 2-years return period design flood discharge $\left(Q_{2}\right)$ for Madukoro Area drainage channel, as well as 2-years return period $\left(Q_{2}\right)$ and 25-years $\left(Q_{25}\right)$ for West Flood Canal. Table 8 showed that for the case of existing condition, the flood level elevation was $+2.30 \mathrm{~m}$. When the gate and pump were operated, the flood level elevation was $+1.85 \mathrm{~m}$. Flood level was actually lower when compared with water gate existence. This was because the simulation was conducted with 2-years return period design flood discharge for West Flood Canal (small discharge).

Table 8. Simulation results for the case of 2-years return period design flood discharge in West Flood Canal $\left(Q_{2}\right)$

\begin{tabular}{ll}
\hline Drainage condition & Average flood level $(+\mathrm{m})$ \\
\hline $\begin{array}{l}\text { With gate and pump } \\
\text { (existing) }\end{array}$ & 2.30 \\
Without gate and pump & 1.85 \\
\hline
\end{tabular}

Table 9 showed that on existing condition, the elevation of flood level was $+2.30 \mathrm{~m}$. When the gate and pump were operated, the flood level elevation was $+2.56 \mathrm{~m}$. The existence of Watergate and pump infrastructure is quite significant in flood controlling at large discharge on West Flood Canal.

Table 9. Simulation results for the case of 25-years return period design flood discharge in West Flood Canal $\left(Q_{25}\right)$

\begin{tabular}{ll}
\hline Drainage condition & Average flood level $(+\mathrm{m})$ \\
\hline $\begin{array}{l}\text { With gate and pump } \\
\text { (existing) }\end{array}$ & 2.30 \\
Without gate and pump & 2.56 \\
\hline
\end{tabular}

\subsection{Recommendation for Flood and Coastal Flood Controlling}

Several recommendations according to its priority scale that could be suggested for the flood and coastal flood controlling in Madukoro Area are by participation of the community in maintaining the drainage channel capacity and operational pattern on the gate and water pump maintenance that are arranged in a way so that inundation would not occur for a long time, adding the number of water pumps, as well as raising the elevation of overflowed levee. Operational pump was illustrated in Figure 18.

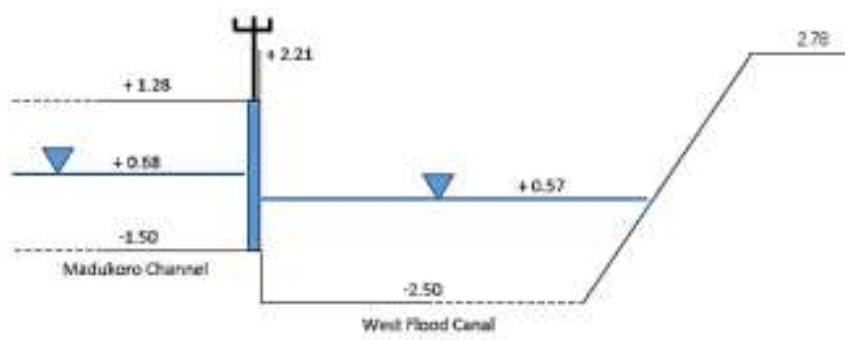

Figure 18. Operational scheme of Madukoro water gate with 2-years return period condition $\left(Q_{2}\right)$

Madukoro water gate is closed when the water level in West Flood Canal is above $-1.50 \mathrm{~m}$, and water pump in Madukoro is turned on. The Madukoro water gate is opened when the water level in the West Flood Canal is below $-1.50 \mathrm{~m}$, therefore the water from Madukoro Channel flows by gravity to West Flood Canal. HECRAS simulation result of the minimum discharge 
condition showed that the water level in the West Flood Canal was of +0.57 (still above elevation of -1.50 ), therefore the gate must be closed.

Height of levee is elevated in each Madukoro Area drainage channel reach with condition as follows:

a) Ronggolawe River levee that is under the elevation of +3.00 is increased until elevation of +3.00 . The other that is already above the elevation of +3.00 is stayed put.

b) Karangayu River levee is increased until elevation of $+3.00$

c) Artery Channel and Madukoro levees are increased until elevation of +2.65

Adding the number of water pumps is not particularly significant in lowering the water level at time of flood peak, but it would be very significant in increasing the flood recession time (Figure 19). The inundation height was measured from the difference of highest flood level elevation with average land elevation. Recession time was calculated from the time highest flood level elevation is reached until the flood level decrease and is under the levee lowest elevation. Comparison of recession time between simulation results using 2 pumps and 4 pumps operation was shown in Table 10. Average land elevation in Madukoro area is of $+1.6 \mathrm{~m}$; lowest levee elevation in Madukoro Channel is of +0.86 m (RS. 500).

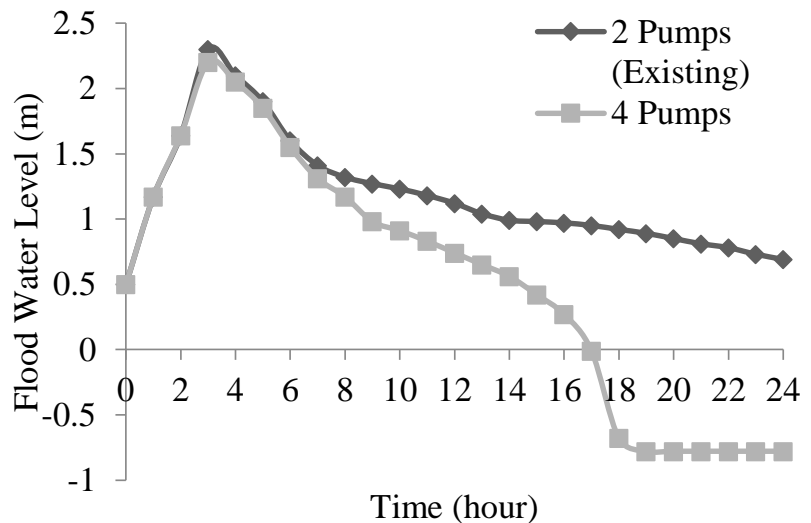

Figure 19. Hydrograph of flood level from the result of simulating the pump addition

Table 10. Recession time based on simulation results with water pump addition with 2-years return period $\left(Q_{2}\right)$

\begin{tabular}{lll}
\hline Pumps Amount & $\begin{array}{l}\text { Average } \\
\text { inundation } \\
\text { height }(\mathrm{m})\end{array}$ & $\begin{array}{l}\text { Recession time } \\
\text { (hours) }\end{array}$ \\
\hline $\begin{array}{l}\text { 2 pumps } \\
\text { (existing) }\end{array}$ & 0.7 & 13 \\
4 pumps & 0.6 & 7 \\
\hline
\end{tabular}

\section{CONCLUSION AND SUGGESTION}

\subsection{Conclusions}

Several conclusions from the result of this research are as follows:

a) In drainage channel of the Madukoro Area, flood runoff occurred was about $80 \%$ on all channel reach with 2-years return period design flood discharge. Average height of the flood level was of $0.7 \mathrm{~m}$ above the average land surface in Madukoro Area.

b) In West Flood Canal, the flood runoff occurred was about $40 \%$ of the channel reach with 50-years return period flood discharge $\left(Q_{50}\right)$, and runoff height reached $1.91 \mathrm{~m}$ above the levee.

c) Flow on the Madukoro Area drainage channel, particularly on West Flood Canal, was very affected by the flood discharge from the upstream and tidal from the downstream/estuary of the West Flood Canal.

d) The height of the flood level in Madukoro Area was not affected by the tidal rise (coastal flood) if the water gate is kept shut. The Madukoro Area would suffer from coastal flood if the water gate is opened.

e) Land subsidence influenced the flood level elevation on West Flood Canal. Flood level rise was occurred of about $10-40 \mathrm{~cm}$.

f) Flood controlling by elevating the levee could be conducted but is not really effective. If the construction is not strong enough and breached, the flood effect would turn worse in Madukoro Area. Infrastructure should be added more, in form of watergate and water pump on every junction between the housing channel and collector channel.

g) The role of drainage infrastructure (watergate and water pump) is very important in Madukoro Area flood controlling. Adding the water pump number from 2 pumps into 4 and 6 pumps were not really significant in decreasing the water level at flood peak but would be very significant in increasing the flood's recession time of about 6-8 hours.

h) The participation from community is very needed in order to maintain the drainage channel storage capacity of Madukoro Area.

\subsection{Suggestions}

Several suggestions that could be proposed from this research result are as follows:

a) Cooperation/sharing pattern between stakeholders (Public Works Office of Semarang City, River Basin Major Agency of Pemali Juana, Office of Public Works Water Resources and Spatial Planning of Central Java Province, and the community) in the integrated effort of flood control in Madukoro Area. 
b) Priorities for the flood and coastal flood controlling in the Madukoro Area are by operational pattern of the gates and water pumps. This research is still far from perfect, therefore further research that is focused on the pump operation simulation should be conducted.

Further studies on the flood and coastal flood management priority are needed, as well as on the levee enhancement and water pumps addition, for example on retention pond and others.

\section{REFERENCES}

Arief, et. al., 2012. Pemetaan Risiko Bencana Banjir Rob Kota Semarang. Yogyakarta, Geospatial Information Science and Engineering.

BAPPEDA Semarang City, 2011. Peta Amblesan Tanah Kota Semarang [Map of Land Subsidence in Semarang City]. Semarang: BAPPEDA Semarang City.

Cabral, et. al., 2015. Hydrologic and Hydraulic Modelling integrated with GIS: A Study of the Acarau River Basin - CE. Journal of Urban and Environmental Engineering, 8(2), pp. 167-174.

JICA, 2000. Final Report The Detailed Design of Flood Control, Urban Drainage and Water Resourcess Development In Semarang In Republic Indonesia (Componenet B : Jatibarang Multipurpose Dam Construction). Semarang: BBWS Pemali Juana.

NASA, 2017. Global Climate Change. [Online] Available at: https://climate.nasa.gov/vital-signs/sealevel/

[Accessed 12 June 2017].
PT. Tera Buana Manggala Jaya, 2007. Penyusunan Dokumen Master Plan Drainase Kota Semarang [Masterplan of Drainage Design in Semarang City]. Semarang.

Soedarsono, 2007. Kondisi Geologi dan Geomorfologi Kaitannya dengan Degradasi Lingkungan di Kota Semarang [Geological and Geomorphological Condition in Semarang City related to Environmental Degradation]. Jurnal Lingkungan Sultan Agung, 1(1), pp. 29-41.

Sri Harto, 2000. Hidrologi Teori Masalah Penyelesaian [Hydrology, Theory, Problems, and Solving]. Yogyakarta: Nafiri Offset.

Suripin, 2003. Sistem Drainase Perkotaan yang Berkelanjutan [Sustainable Urban Drainage System]. Yogyakarta: Penerbit Andi.

Triatmodjo, B., 2008. Hidrologi Terapan [Applied Hydrology]. Yogyakarta: Beta Offset.

Wirasatriya et. al., 2006. Kajian Kenaikan Muka Air Laut Sebagai Landasan Penanggulangan Rob di Pesisir Kota Semarang [Study of Sea Water Level Rise as Guideline for Tidal Flood Mitigation in Semarang City]. Jurnal Pasir Laut, 1(2), pp. 31-42.

Yuswardhanu, 2009. Studi Pemanfaatan Waduk-waduk Untuk Pengendalian Banjir Sungai Garang Kota Semarang Provinsi Jawa Tengah [Study on Dam Function for Flood Control of Garang River in Semarang City, Central Java Province]. Yogyakarta, 1st Conference on Geospatial Information Science and Engineering. 